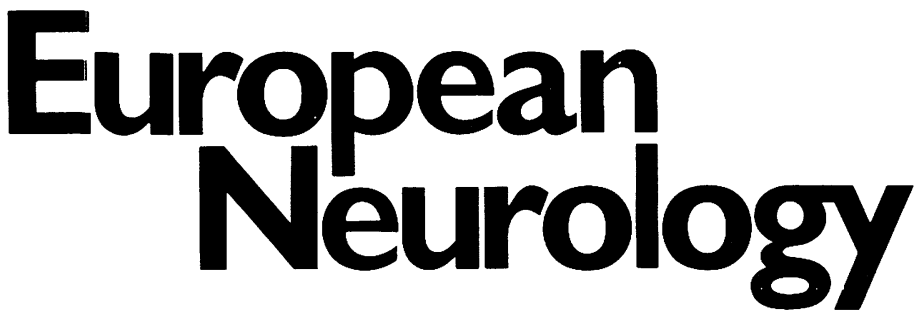

Founded 1897 as 'Monatsschrift für Psychiatrie und Neurologie', continued 1957-1967 as 'Psychiatria et Neurologia'

Foundiers: C. Wernicke and Th. Ziehen.

Successors: K. Bonhoeffer (1912-1938), J. Klaesi (1939-1967),

E. Grünthal (1953-1967)

\section{Editor-in-Chief}

H.E. Kaeser, Basel

\section{Associate Editors}

C. Loeb, Genova

H.-G. Mertens, Würzburg

U.K. Rinne, Turku

H. vander Eecken, Ghent

\section{Editorial Board}

L. Barraquer Boardas, Barcelona

S. Feldman, Jerusalem

P. Huber, Bern

A. Kreindler, Bucharest

H.J. Lehmann, Essen

C. Pallis, London

E. Satoyoshi, Tokyo

F. Seinelberger, Vienna

J. Ulrich, Basel

F. Vasella, Bern
Advisory Board

Electromyography

H.P. Ludin, Bern

Neuroendocrinology

P.O. Lundberg, Uppsala

Cerebrospinal Fluid

H.B. Rieder, Basel

Electroencephalography

G. Scollo-Lavizzari, Basel

Evoked Potentials

W. Tackmann, Bonn

Ophthalmology

O. Meienberg, Basel 


\section{Universitäts- \\ Bibliothek \\ München}

S. Karger - Medical and Scientific Publishers - Basel - München - Paris - London - New York - Tokyo · Sydney

\section{Drug Dosage}

The authors and the publisher have exerted every effort to ensure that drug selection and dosage set forth in this text are in accord with current recommendations and practice at the time of publication. However, in view of ongoing research, changes in government regulations, and the constant flow of information relating to drug therapy and drug reactions, the reader is urged to check the package insert for each drug for any change in indications and dosage and for added warnings and precautions. This is particularly important when the recommended agent is a new and/or infrequently employed drug.
All rights reserved.

No part of this publication may be translated into other languages, reproduced or utilized in any form or by any means, electronic or mechanical, including photocopying, recording, microcopying, or by any information storage and retrieval system, without permission in writing from the publisher or, in the case of photocopying, direct payment of a specified fee to the Copyright Clearance Center (see 'Information for Readers and Subscribers').

C Copyright 1984 by

S. Karger AG, P.O. Box, CH-4009 Basel (Switzerland) Printed in Switzerland by Thür AG Offsetdruck, Pratteln 
No. 1 The Anticonvulsant Effect of the Benzodiazepine Antagonist, Ro 15-1788: An EEG Study in 4 Cases

Scollo-Lavizzari, G.

CAT Scan and Immunohistochemical Findings in a Case of Cerebral Thromboangiitis obliterans (Buerger's Disease)

Kessler, C.; Reuther, R.; Berlit, P.; Carls, C.; Hofmann, W.

The Palmomental Reflex. Clinical Study of 300 Cases

Marti-Vilalta, J.L.; Graus, F.

The Diagnostic Value of Three Common Primitive Reflexes

Isakov, E.; Sazbon, L.; Costeff, H.; Luz, Y.; Najenson, T.

Complicated Migraine in AS Hemoglobinopathy

Bussone, G.; La Mantia, L.; Boiardi, A.; Parati, E.A.; Frediani, F.; Testa, D. . . . . . .

Chorea and Polycythaemia

Bruyn, G.W.; Padberg, G.

CT Findings of the Interval Form of Carbon Monoxide Poisoning Compared with Neuropathological Findings

Kobayashi, K.; Isaki, K.; Fukutani, Y.; Kurachi, M.; Eboshida, A.; Matsubara, R.; Yamaguchi, N. . . . . . . . . . . . . . . . . . .

Characteristic Clinical Aspects of Parkinson Patients with Intellectual Impairment

Piccirilli, M.; Piccinin, G.L.; Agostini, L. . . . . . . . . . . . . . . .

Efficacy of Baclofen in Trigeminal Neuralgia and Some Other Painful Conditions. A Clinical Trial

Steardo, L.; Leo, A.; Marano, E. . . . . . . . . . . . . . . . . . . .

Computerized Cranial Tomography in Presymptomatic and Hepatic Form of Wilson's Disease

Dettori, P.; Rachele, M.G.; Demelia, L.; Pelaghi, A.E.; Nurchi, A.M.; Aromando, P.; Giagheddu, M.

Announcement

No. 2 Presence of a Tamm-Horsfall-Like Glycoprotein in the CSF of Neurology Patients. First Results

Schuller, E.; Bringuier, A.F.; Hartmann, L.

Beta-Endorphin-, Leucine Enkephalin- and Methionine Enkephalin-Like Immunoreactivity in Human Cerebrospinal Fluid. Simultaneous Determination and Relation to Neurological Disorders

Neuser, D.; Lesch, K.P.; Stasch, J.P.; Przuntek, H.

Continuous Intraoperative EEG Monitoring during Carotid Surgery

Meneghetti, G.; Deriu, G.P.; Saia, A.; Giaretta, D.; Ballotta. E. 
Effect of Piracetam in Huntington's Chorea

Destée, A.; Petit, H.; Warot, P.

Oculogyric Crisis Induced by Lithium Carbonate

Sandyk, R.

Deep Dyslexia in a Patient with Crossed Aphasia

Sartori, G.; Bruno, S.; Serena, M.; Bardin, P. . . . . . . . . . . . . . . . . . 95

Triiodothyronine $\left(\mathrm{T}_{3}\right)$ Toxicosis with Hypokalemic Periodic Paralysis

Sunohara, N.; Satoyoshi, E. . . . . . . . . . . . . . . . . . . . . . . 100

Hyperammonemia and Valproate-Induced Alterations of the State of Consciousness. A Report of 8 Cases

Zaccara, G.; Paganini, M.; Campostrini, R.; Arnetoli, G.; Zappoli, R.; Moroni, F. . . . 104

Progressive Multifocal Leukoencephalopathy Presenting as a Single Mass Lesion

Vanneste, J.A.L.; Bellot, S.M.; Stam, F.C.

Complete Sensory and Motor Recovery from Anterior Spinal Artery Syndrome after Sprain of the Cervical Spine. A Case Report

Foo, D.; Rossier, A.B.; Cochran, T.P.

Cerebral Infarctions with Negative CT Scans

Johansson, $\mathrm{T}$.

Investigation of the Blood-Brain Barrier for IgG in Inflammatory Syndromes of the Central Nervous System

Guenther, W.; Neu, I.S.

Locked-In Syndrome in Acute Inflammatory Polyradiculoneuropathy

Loeb, C.; Mancardi, G.L.; Tabaton, M.

No. 3 31P Nuclear Magnetic Resonance Studies of Anoxia in Aged Rat Brain

Cohen, M.M.; Kopp, S.J.; Pettegrew, J.W.; Glonek, T.

Distal Myopathy of Gowers: A Reappraisal

Furukawa, T.; Odajima, N.; Watabiki, S.; Tsukagoshi, H.

Internuclear Ophthalmoplegia in Tuberculous Meningitis. A Report of Two Cases

Sandyk, R.; Brennan, M.J.W.

Typical and Reverse Bobbing: A Case with Localizing Value

Brusa, A.; Firpo, M.P.; Massa, S.; Piccardo, A.; Bronzini, E.

Symptomatic Xanthogranuloma of the Third Ventricle: A Clinicopathological Report

Gherardi, R.; Nguyen, J.P.; Gaston, A.; Poirier, J. . . . . . . . . . . . . . . . 156

Baclofen in Hemifacial Spasm

Sandyk, R.

Cardiac Involvement in Juvenile Ceroid Lipofuscinosis of the Spielmeyer-Vogt-Sjögren

Type: Prospective Noninvasive Findings in Two Siblings

Michielsen, P.; Martin, J.J.; Vanagt, E.; Vrints, C.; Gillebert, T.; Snoeck, J. . . . . 166

Pathological Study of the Sural Nerve in Fabry's Disease

Gemignani, F.; Marbini, A.; Bragaglia, M.M.; Govoni, E.

Clofibrate-Induced Myotoxicity in Rats. Temporal Profile of Myopathology

Afifi, A.K.; Hajj, G.A.; Saad, S.; Tekian, A.; Bergman, R.A.; Bahuth, N.B.; Abourizk, N. 182

Paralysis of Upward Gaze as a Presenting Symptom of Vitamin $B_{12}$ Deficiency

Sandyk, R.

Cyclic AMP in the Cerebrospinal Fluid of Patients with Recent Cerebral Infarction

Mršulja, B.B.; Djuričić. B.M.; Kostić, V.S.; Panić, M.

Multiple Stroke due to Multiple Vascular Malformation of the Brain

Bugiani, O. 
Rapidly Progressive Subacute Sclerosing Panencephalitis: An Ultrastructural and Immunoperoxidase Study

Dhib-Jalbut, S.; Liwnicz, B.H. . . . . . . . . . . . . . . . . . . . . . . . 211

Blink Reflex in Hemiplegia

Girlanda, P.; Dattola, R.; Messina, C. . . . . . . . . . . . . . . . . . . 221

Announcements . . . . . . . . . . . . . . . . . . . . . 228

No. 4 Cerebral Schistosomiasis Presenting as a Brain Tumor Gjerde, I.O.; Mörk, S.; Larsen, J.L.; Huldt, G.; Skeidsvoll, H.; Aarli, J.A. . . . . . . . 229

Guillain-Barré Syndrome Associated with Acute Cytomegalovirus Mononucleosis Syndrome

Mozes, B.; Pines, A.; Sayar, Y.; Kaplinsky, N.; Frankl, O. . . . . . . . . . . . . . . 237

Brain Stem Vascular Malformation Simulating a Hemorrhagic Metastasis: Report of a Case with Pathologic Correlation

Scardigli, K.; Biller, J.; Ghobrial, M.; Ross, E.; Badrinath, K. . . . . . . . . . . . . . 240

Electrophysiological Studies in Primary Biliary Cirrhosis

Zeitlhofer, J.; Mamoli, B.; Dragosics, B.; Knoflach, P. . . . . . . . . . . . . . . . 247

Comparative Study of Posturography and Electrooculography in at-Risk Subjects for Huntington's Disease

Valade, D.; Davous, P.; Rondot, P. . . . . . . . . . . . . . . . . . . . . . 252

Fahr's Disease Associated with Cystic Astrocytoma

Morimoto, K.; Mogami, H.; Ozaki, K. . . . . . . . . . . . . . . . . . 265

Chronic Haloperidol Administration Enhances the $\gamma$-Aminobutyric Acid Level in the Rat Striatum without Altering the Glutamate Level

Kornhuber, J.; Kim, J.S.; Kornhuber, M.E.; Kornhuber, H.H.

Hemangiopericytic Meningioma of the Pineal Region. Case Report

Lesoin, F.; Bouchez, B.; Krivosic, I.; Delandsheer, J.M.; Jomin, M. . . . . . . . . . . . 274

Chorea and Systemic Lupus erythematosus. A Critical Review

Bruyn, G.W.; Padberg, G. . . . . . . . . . . . . . . . . . . . . . . . . . 278

Cerebrospinal Fluid Prostaglandin $F_{2 \alpha}$ in Stroke Patients: No Relationship to the Degree of Neurological Deficit

Kostić, V.S.; Djuričić, B.M.; Mršulja, B.B. . . . . . . . . . . . . . . . . . . . . . 291

A Childhood Form of Huntington's Disease Associated with Marked Pyramidal Signs

Katafuchi, Y.; Fujimoto, T.; Ono, E.; Kuda, N. . . . . . . . . . . . . . . . . . . 296

Cimetidine Neurotoxicity. EEG and Behaviour Aspects

Van Sweden, B.; Kamphuisen, H.A.C. . . . . . . . . . . . . . . . . . . 300

Isoelectric Focusing Followed by Silver Staining. A Suitable Method for Routine Investigation of Cerebrospinal Fluid Proteins

Wikkelsö, C.; Andersson, M.; Andersson, R.; Blomstrand, C. . . . . . . . . . . . 306

No. 5 DSIP · Delta-Sleep-Inducing Peptide

Introduction

Kaeser, H.E.

Cellular Localization of Binding Sites for ${ }^{3} \mathrm{H}$-DSIP on Neurones of Cultured Rat Brain

Stem

Hösli, E.; Schoenenberger, G.A.; Hösli, L. 
Characterization, Properties and Multivariate Functions of Delta-Sleep-Inducing Peptide (DSIP)

Schoenenberger, G.A.

Some Pharmacological Effects of Delta-Sleep-Inducing Peptide (DSIP)

Scherschlicht, R.; Aeppli, L.; Polc, P.; Haefely, W.

Effects of DSIP on Narcolepsy

Schneider-Helmert, D.

DSIP in Insomnia

Schneider-Helmert, D.

DSIP in the Treatment of Withdrawal Syndromes from Alcohol and Opiates

Dick, P.; Costa, C.; Fayolle, K.; Grandjean, M.E.; Khoshbeen, A.; Tissot, R

Therapeutic Effects of Delta-Sleep-Inducing Peptide (DSIP) in Patients with Chronic, Pronounced Pain Episodes. A Clinical Pilot Study

Larbig. W.; Gerber, W.D.; Kluck, M.; Schoenenberger, G.A.

A Clinical Trial with DSIP

Kaeser, H.E.

No. 6 Vasculitis: Immunological Aspects

Hasler, F.

New Aspects of Thromboangiitis obliterans (von Winiwarter-Buerger's Disease)

Berlit, P.; Kessler, C.; Reuther, R.; Krause, K.-H

Cerebral Angiography in Vasculitis Affecting the Nervous System Kendall, B.

Cytostatic Drugs in the Treatment of Severe Vasculitides. Indications, Results and Risks Kaeser, H.E.

Giant Cell Arteritis and Its Variants

Gerber, N.J. . . . . . . . . . . .

Stroke in Childhood and Adolescence Isler, W.

Centronuclear Myopathy with Special Consideration of the Adult Form Goebel, H.H.; Meinck, H.M.; Reinecke, M.; Schimrigk, K.; Mielke, U.

Chorea and Systemic Lupus erythematosus. A Critical Review Bruyn, G.W.; Padberg, G.

Maturation of the Blink Reflex in Infants Vecchierini-Blineau, M.F.; Guiheneuc, P.

Sarcoidosis of the Peripheral Nerve: Clinical, Electrophysiological and Histological Study of Two Cases

Galassi, G.; Gibertoni, M.; Mancini, A.; Nemni, R.; Volpi, G.; Merelli, E.; Vacca, G. . 459

How Specific Are Periodic Complexes in the Diagnosis of Herpes simplex Encephalitis?

Roches, J.C.; Probst, A.; Scollo-Lavizzari, G. . . . . . . . . . . . . . . . . . . . . 466

Vasculitis in the Central Nervous System - Contribution of Angiography

Kendall, B.

Meige's Syndrome: Acute and Chronic Responses to Clonazepan and Anticholinergics Hípola, D.; Mateo, D.; Giménez-Roldán, S.

Motor Dysfunction following Chronic Exposure to a Fluoroalkane Solvent Mixture Containing Nitromethane

Sandyk, R.; Gillman, M.A.

Author Index

Subject Index 


\title{
New Aspects of Thromboangiitis obliterans (von Winiwarter-Buerger's Disease)
}

\author{
P. Berlit, C. Kessler, R. Reuther, K.-H. Krause \\ Department of Neurology, Ruprecht-Karls-University, Heidelberg, FRG
}

Key Words. Immunovasculitis. Immunohistochemical findings - Anti-elastin antibodies . $\operatorname{IgE} \cdot$ Azathioprine

\begin{abstract}
The existence of thromboangiitis obliterans as a clinical entity has been a matter of debate for many years. In contrast to other immunovasculitides there is no organ involvement while peripheral vessels are affected. Heavy smokers under 40 years of age have a high predisposition for the disease. The cerebral form shows relapsing brain infarctions which can be visualized in CCT while panarteriography remains negative. Apart from unspecific inflammatory signs in blood and CSF there are distinctive laboratory findings proving the autoimmunological character of von Winiwarter-Buerger's disease. In the serum anti-elastin antibodies, IgE and anticollagen antibody activity are detectable. In 3 patients the authors detected specific immunohistochemical findings in a biopsy specimen of the temporal artery. In addition to platelet-inhibiting substances corticoids in acute and azathioprine in chronic treatment becomes necessary.
\end{abstract}

In 1879 , von Winiwarter in Vienna described the segmental inflammatory changings in medium-sized arteries and veins in the amputated leg of a 57 -year-old man, a disease he called endarteriitis obliterans. He underlined the possible role of coldness in the development of the gangrene in his case. Buerger [1908] changed the term endarteriitis into thromboangiitis obliterans and showed that the stenoses and occlusions in this disease are caused by repeated thromboses. In 19 amputated legs he demonstrated as characteristic findings the alternation of inflammatory thromboses in different states of development and relatively normal segments in the single affected vessel. In these cases he 
detected an increased prevalence in Jews of Russian or Polish origin.

During the following years different authors named characteristic features of the disease: (1) A high predisposition for young men under 40 years of age. (2) The vessels of the wrist and hand are often included in the inflammatory process [Allen, 1929]. (3) There is a close association between cigarette smoking and the activity of the disease [Mever, 1918; Silbert, 1945]. (4) There is often a migratory superficial thrombophlebitis accompanying the vasculitis.

But in spite of all these typical features the existence of thromboangiitis obliterans as a clinical entity has been questioned repeatedly. Especially the differentiation from inflammatory forms of arteriosclerosis gave cause for controversial opinions. One of the reasons for this history of the disease may be the lack of organ involvement in von Winiwarter-Buerger's disease, which is in contrast to almost all other immunovasculitides. In view of this fact it is not surprising that the cerebral form of thromboangiitis obliterans has been put in question even more than the peripheral disease. Jäger [1932] was the first to mention the existence of a cerebral involvement in his cases, a few years later Spatz [1935] and Lindenberg and Spatz [1939] demonstrated two forms of cerebral thromboangiitis obliterans (CTAO): (1) multiple unsystematic cerebral infarctions in involvement of medium-sized vessel, and (2) the symmetrical granular atrophy caused by involvement of small leptomeningeal arteries.

The significance of the second finding had been challenged early when Fisher [1957] and later Zollinger [1967] demonstrated that different forms of occlusive disease in the small endarteries of the brain result in the same picture. For neuropathologists the differentiation between CTAO and arteriosclerosis was the cardinal problem. The differential diagnosis to other forms of cerebral vasculitis was not as big a problem because pathological studies showed no involvement of the media or the elastica in the inflammatory process in CTAO.

Which are the diagnostic criteria that could help us today in detecting CTAO? In the Neurologic Clinic in Heidelberg we saw, during a period of 12 years, 7 patients suffering from this disease (i.e. $0.05 \%$ of all patients and $0.3 \%$ of all brain infarctions between 1970 and 1982). All patients were young men and heavy smokers - the onset of neurological symptoms was usually before the thirtieth year. In 3 cases the neuropathological examination confirmed the diagnosis, posthumous. In 3 other patients whom we saw during the last 2 years extensive rheumatological and immunological examinations could be carried out.

In all patients there was an astonishing similarity of the clinical history. They all suffered from repeated brain infarctions of different localization over months or even years. While in cranial computed tomography (CCT) hypodensive areas according to the clinical neurological findings could be demonstrated, there were no pathological changes in the panarteriography of the brainsupporting vessels. Extensive cardiological examinations including echocardiography and in 1 patient even a cardiac-catheter revealed no possible source for repeating brain embolism from the heart. The areas of the medial and the posterior cerebral artery were the regions most often affected. The neurological signs as well as the CCT-findings improved partially within few weeks leaving minor residual symptoms, especially visual 
field reductions. Additional findings in 1 patient were major epileptic seizures and an ischemic optic neuritis [Kessler et al., 1984]. Another patient - a farmer - twice developed the brain infarctions during work outdoors [Kessler et al., 1983].

In all cases unspecific inflammatory changes in blood and/or cerebrospinal fluid (CSF) lead towards a vasculitic process. In CSF an increase of cells up to 100 cells $/ \mathrm{mm}^{3}$ as well as an increased protein concentration about $120 \mathrm{mg} / 100 \mathrm{ml}$ could be demonstrated in several patients; in some patients at different times of examination the findings were normal as well as pathological. Specific laboratory findings were an increased titre of antielastin antibodies of up to $1: 1,400$ (normal $1: 8)$ and an increased serum IgE of up to $300 \mathrm{U} / \mathrm{ml}$ (normal range up to $100 \mathrm{U} / \mathrm{ml}$ ).

In 3 cases a biopsy of the temporal artery was performed. In all 3 patients there were distinct immunohistochemical findings while the pathohistological examination revealed a morphologically normal vessel wall. The results of the immunohistochemical examination with a direct immunofluorescent technique are shown in table I. An important result is the deposit of immunoglobulins and complement components especially in the vasa vasorum. Early investigators already suggested that the inflammation of the vasa vasorum might be the primary process in von Winiwarter-Buerger's disease [Buerger, 1908; Jäger, 1932]. The immunohistochemical findings as well as the increase of anti-elastin antibodies and IgE in the serum are signs of an autoimmunological process which one does not find in arteriosclerotic disease. In 20 patients suffering from thrombotic brain infarctions anti-elastin antibody titres and serum IgE were within the normal range. While the presence of anti-elastin antibodies in
Table I. Immunohistochemical findings in a biopsy specimen of the temporal artery in 3 patients with CTAO

IgG IgA IgM Cla C3b C3d C9

\begin{tabular}{llllllll}
\hline Pat. 1 & & & & & & & \\
Intima & - & - & - & + & + & + & - \\
Elastica interna & - & - & - & - & - & - & - \\
Media & - & - & - & - & - & - & - \\
Vas vasorum & - & + & + & - & - & - & - \\
Pat. 2 & & & & & & & \\
Intima & + & + & + & + & + & + & - \\
Elastica interna & + & + & - & + & - & - & - \\
Media & - & - & - & - & - & - & - \\
Vas vasorum & ++ & + & + & - & + & + & - \\
Pat. 3 & & & & & & & \\
Intima & + & + & + & + & + & + & - \\
Elastica interna & + & + & - & - & - & - & + \\
Media & - & - & - & - & - & - & - \\
Vas vasorum & ++ & + & + & - & + & + & - \\
\hline
\end{tabular}

CTAO seems to be a common and typical finding [Bollinger et al., 1979; Horsch et al., 1978] the meaning of the increased IgE remains unclear. This immunoglobulin is a sign of an allergic inflammatory process and often found in systemic vasculitis with respiratory tract involvement [Berlit et al., 1982].

Further studies are necessary to clarify the meaning of the immunohistochemical findings in the vessel wall. But in young stroke patients the examination of a biopsy of the temporal artery could be a very helpful diagnostic procedure [Berlit and Kessler, 1983] in detecting CTAO. Two preconditions for this procedure are the panarteriography of the brain-supporting vessels performed in advance and a surgical technique for taking the biopsy specimen from a branch of the temporal artery. Taking the possible necessity of a later externa-interna bypass into consider- 
Table II. Clinical and laboratory findings in different vasculitides [modified after Berlit et al. 1983]

\begin{tabular}{llllll}
\hline $\begin{array}{l}\text { Poly- } \\
\text { arteritis } \\
\text { nodosa }\end{array}$ & $\begin{array}{l}\text { Lupus } \\
\text { erythematosus }\end{array}$ & $\begin{array}{l}\text { Arteritis } \\
\text { temporalis }\end{array}$ & $\begin{array}{l}\text { Allergic } \\
\text { granulo- } \\
\text { matosis }\end{array}$ & $\begin{array}{l}\text { Wegener's } \\
\text { granulo- } \\
\text { matosis }\end{array}$ & $\begin{array}{l}\text { Thromboangiitis } \\
\text { obliterans }\end{array}$ \\
\hline
\end{tabular}

\begin{tabular}{|c|c|c|c|c|c|c|}
\hline \multicolumn{7}{|l|}{ Clinical findings } \\
\hline $\mathrm{CNS}$ & ++ & ++ & + & ++ & + & + \\
\hline PNS & +++ & + & + & ++ & + & $\varnothing$ \\
\hline Muscle & +++ & ++ & +++ & $\varnothing$ & + & $\varnothing$ \\
\hline Kidney & ++ & ++ & $\varnothing$ & + & +++ & $\varnothing$ \\
\hline Liver & + & + & + & + & + & $\varnothing$ \\
\hline Heart & ++ & ++ & + & +++ & + & $\varnothing$ \\
\hline Lung & + & + & $\varnothing$ & +++ & +++ & $\varnothing$ \\
\hline Intestinal tract & ++ & ++ & + & + & ++ & $\varnothing$ \\
\hline$\overline{\text { Skin }}$ & ++ & +++ & + & ++ & ++ & $\varnothing$ \\
\hline Ankles & ++ & +++ & ++ & + & + & $\varnothing$ \\
\hline Peripheral vessels & $\varnothing$ & + & +++ & + & + & +++ \\
\hline Age & $50-60$ & $30-40$ & $>50$ & $40-50$ & $40-50$ & $25-35$ \\
\hline$\delta: q$ & $2: 1$ & $1: 3$ & $1: 2$ & $2,5: 1$ & $3: 2$ & $6: 1$ \\
\hline
\end{tabular}

\section{Laboratory findings}

Erythrocyte sedimentation rate Eosinophilia

C-reactive protein

Rheumatoid factor

Anti-elastin antibodies

Immunoglobulin A

G

E

Complement C 3

$\mathrm{HB}_{\mathrm{s}}$-antigen/anti-HBs

CSF changings

Tissue antigens

Immunohistochemical

findings in biopsy

specimen from

\begin{tabular}{llll}
$\wedge \wedge$ & $\wedge \wedge$ & $\wedge \wedge \wedge$ & $\wedge \wedge$ \\
++ & $\varnothing$ & $\varnothing$ & ++ \\
++ & + & + & + \\
++ & ++ & $\varnothing$ & + \\
\hline$\varnothing-++$ & $\varnothing-++$ & $\varnothing$ & $\varnothing$ \\
$\wedge \wedge \wedge$ & normal & normal & norm \\
normal & $\wedge \wedge \wedge$ & $\wedge$ & norm \\
normal & normal & $\wedge$ & norm \\
normal & normal & normal & $\wedge \wedge$ \\
$\vee \vee$ & $\vee \vee$ & $\wedge$ & norm \\
$\vee$ & $\vee \vee$ & $\wedge \wedge$ & norm \\
++ & $\varnothing$ & + & $\varnothing$ \\
++ & ++ & + & + \\
$?$ & HLA-B8, Al5 & HLA-B8, Al0 & $?$ \\
++ & ++ & +++ & + \\
muscle & skin & temporal & skin \\
kidney & & artery &
\end{tabular}

\begin{tabular}{lll}
$\wedge \wedge$ & $\wedge \wedge \wedge$ & $\wedge$ \\
\hline+++ & + & $\varnothing$ \\
+ & + & ++ \\
+ & + & $\varnothing$ \\
\hline$\varnothing$ & $\varnothing$ & +++ \\
normal & $\wedge \wedge$ & normal \\
normal & $\wedge$ & normal \\
normal & $\vee$ & normal \\
\hdashline$\wedge$ & $\wedge \wedge$ & $\wedge \wedge$ \\
normal & normal & normal \\
normal & normal & $\wedge \wedge$ \\
$\varnothing$ & $\varnothing$ & $\varnothing$ \\
+ & $\varnothing-+$ & + \\
$?$ & HLA-B8 & HLA-A9. HLA-B5 \\
+ & ++ & ++ \\
skin & kidney & temporal \\
& lung & artery
\end{tabular}

$+++=$ Usually found; $++=$ often found; $+=$ seldom found: $\varnothing=$ not found; $\wedge \wedge \wedge$ = usually increased; $\wedge \wedge$ or $\vee \vee=$ often increased or lowered; $\wedge$ or $\vee=$ seldom increased or lowered.

ation, the main stem of the vessel should be spared.

In addition to these signs of humoral immune mechanisms in thromboangiitis obliterans Adar et al. [1983] described an increased stimulation index of cellular sensitivity to human collagen. All these findings are strong arguments for the distinctive character of CTAO as an autoimmunological vasculitis.

Another finding of interest is the greater prevalence of HLA-A9 and HLA-B5 antigens in patients with von Winiwarter-Buerger's disease [McLoughlin et al., 1976]. In consis- 
tence with the findings of Buerger [1908], the disease shows an increased occurrence in Israel and the Orient.

In the differential diagnosis of CTAO one has to think of focal encephalitis in septic brain embolism; a possible cardiac source of emboli to the brain should be excluded by echocardiography and long-term electrocardiography [Berlit, 1983]. The typical features of CTAO in comparison to some other vasculitides of the brain are summarized in table II. There are some very distinctive diagnostic criteria that help to make a reasonably certain diagnosis of CTAO: (1) male patients, about 30 years old; (2) strong smokers; (3) relapsing brain infarctions in changing localizations, which can be visualized in CCT; (4) negative results in angiography and cardiologic examinations; (5) unspecific inflammatory signs in blood (blood sedimentation rate, C-reactive protein) and CSF (cells and/or protein elevated); (6) anti-elastin antibodies, IgE and anticollagen antibody activity detectable; (7) distinctive immunohistochemical findings in biopsy of the temporal artery, and (8) signs or history of peripheral vessel involvement.

In therapy the autoimmunological character of CTAO should be taken into account. Apart from the obligatory treatment with platelet-inhibiting substances corticoids in the acute situation of a brain infarction and azathioprine in long-term therapy are necessary. Smoking must be strictly forbidden in patients with CTAO.

Altogether the existence of thromboangiitis obliterans von Winiwarter-Buerger as a clinical entity has been defended by careful studies, and today the question asked by Zülch [1969]: 'The cerebral form of von Winiwarter-Buerger's disease - does it exist' should be answered with 'yes'.

\section{References}

Adar, R.; Papa, M.Z.; Halpern, Z.; Mozes, M.; Shosan, S.; Sofer, B.; Zinger, H.; Dayan, M.; Mozes, E.: Cellular sensitivity to collagen in thromboangiitis obliterans. New Engl. J. Med. 308: 1113-1116 (1983).

Allen, E.N.: Thromboangiitis obliterans: methods of diagnosis of chronic occlusive arterial lesions distal to the wrist with illustrative cases. Am. J. med. Sci. 178: 237-244 (1929).

Berlit, P.; Die kardiale Hirnembolie. Nervenarzt 54. 389-399 (1983)

Berlit, P.; Kessler, C.: Immunhistologische Diagnostik bei Schlaganfällen. Psycho 9: 386 (1983).

Berlit, P.; Kessler, C.; Storch, B.; Krause, K.H.: Immunvaskulitis und Nervensystem. Nervenarzt 54 . 497-503 (1983).

Berlit, P.; Möller, P.; Krause, K.H.: Eosinophile Polyneuritis und allergische Angiitis. Nervenarzt 53 : 714-720 (1982).

Bollinger, A.; Hollmann, B.; Schneider, E.; Fontana, A.: Thromboangiitis obliterans: Diagnose und Therapie im Licht neuer immunologischer Befunde. Schweiz. med. Wschr. 109: 537-543 (1979).

Buerger, L.C.: Thrombo-angiitis obliterans: a study of the vascular lesions leading to presenile spontaneous gangrene. Am. J. med. Sci. 136: 567-580 (1908).

Fisher, M.C.: Cerebral thromboangiitis obliterans. Medicine, Baltimore 36: 169-209 (1957).

Horsch, A.K.; Brechmeier, P.; Robert, L.; Horsch, S.: Anti-Elastin-Antikörper bei der Thrombangiitis obliterans (Morbus v. Winiwarter-Buerger). Verh. dt. Ges. inn. Med. 40: 1758-1761 (1978).

Jäger, E.: Zur pathologischen Anatomie der Thrombangiitis obliterans bei juveniler Extremitätengangrän. Virchows Arch. path. Anat. Physiol. 284: 526-583 (1932).

Kessler, C.; Berlit, P.; Reuther, R.; Schwechheimer,. K.: Zur Differentialdiagnose der Thrombangiitis obliterans v. Winiwarter-Buerger. Nervenarzt 54 : 85-91 (1983).

Kessler, C.; Reuther, R.; Berlit, P.; Carls, C.; Hoffmann, W.: CAT-Scan and immunohistochemical findings in a case of cerebral thromboangiitis obliterans (Buerger's disease). Eur. Neurol. 23: 7-11 (1984).

Lindenberg, R.; Spatz, H.: Über die Thrombangiitis 
obliterans der Hirngefässe. Virchows Arch. path. Anat. Physiol. 305: 531-557 (1939).

McLoughlin, G.A.; Helsby, C.R.; Evans, C.C.; Chapman, D.M.: Association of HLA-A9 and HLA-B5 with Buerger's disease. Br. med. J. ii: 1165-1166 (1976).

Meyer, W.: Etiology of thrombo-angiitis obliterans (Buerger). J. Am. med. Ass. 71: 1268-1272 (1918).

Silbert, S.: Etiology of thromboangiitis obliterans. J. Am. med. Ass. 129: 5-17 (1945).

Spatz, H.: Über die Beteiligung des Gehirns bei der v. Winiwarter-Buerger'schen Krankheit. Dt. Z. NervHeilk. 136: 86-141 (1935).

Winiwarter, F. von: Über eine eigentümliche Form der Endarteriitis und Endophlebitis mit Gangrän des Fusses. Arch. klin. Chir. 23: 202-226 (1879).
Zollinger, H.U.: Adaptive Intimafibrose der Arterien. Virchows Arch. path. Anat. Physiol. 342: 154-167 (1967).

Zülch, K.J.: The cerebral form of von WiniwarterBuerger's disease: does it exist? Angiology 20: 6169 (1969).

P. Berlit,

Department of Neurology,

Ruprecht-Karls-University,

D-6900 Heidelberg (FRG) 
Aarli, J.A. 229

Abourizk, N. 182

Aeppli, L. 346

Afifi, A.K. 182

Agostini, L. 44

Andersson, M. 306

Andersson, R. 306

Arnetoli, G. 104

Aromando, P. 56

Badrinath, K. 240

Bahuth, N.B. 182

Ballotta, E. 82

Bardin, P. 95

Bellot, S.M. 113

Bergman, R.A. 182

Berlit, P. 7, 394

Biller, J. 240

Blomstrand, C. 306

Boiardi, A. 22

Bouchez, B. 274

Bragaglia, M.M. 173

Brennan, M.J.W. 148

Bringuier, A.F. 65

Bronzini, E. 151

Bruno, S. 95

Brusa, A. 151

Bruyn, G.W. 26, 278, 435

Bugiani, O. 206

Bussone, G. 22

Campostrini, R. 104

Carls, C. 7

Cochran, T.P. 119

Cohen, M.M. 141

Costa, C. 364

Costeff, H. 17

Dattola, R. 221

Davous, P. 252

Delandsheer, J.M. 274

Demelia, L. 56

Deriu, G.P. 82

Destée, A. 89

Dettori, P. 56

Dhib-Jalbut, S. 211

Dick, P. 364
Djuricić, B.M. 201, 291

Dragosics, B. 247

Eboshida, A. 34

Fayolle, K. 364

Firpo, M.P. 151

Foo, D. 119

Frankl, O. 237

Frediani, F. 22

Fujimoto, T. 296

Fukutani, Y. 34

Furukawa, T. 144

Galassi, G. 459

Gaston, A. 156

Gemignani, F. 173

Gerber, N.J. 410

Gerber, W.D. 372

Gherardi, R. 156

Ghobrial,M. 240

Giagheddu, M. 56

Giaretta, D. 82

Gibertoni, M. 459

Gillebert, T. 166

Gillman, M.A. 479

Giménez-Roldán, $\mathrm{S}$. 474

Girlanda, P. 221

Gjerde, I.O. 229

Glonek, T. 141

Goebel, H.H. 425

Govoni, E. 173

Grandjean, M.E. 364

Graus, F. 12

Guenther, W. 132

Guiheneuc, P. 449

Haefely, W. 346

Hajj, G.A. 182

Hartmann, L. 65

Hasler, F. 389

Hipola, D. 474

Hofmann, W. 7

Hösli, E. 317

Hösli, L. 317

Huldt, G. 229
Isaki, K. 34

Isakov, E. 17

Isler, W. 421

Johansson, T. 124

Jomin, M. 274

Kaeser, H.E. 386, 407

Kamphuisen, H.A.C. 300

Kaplinsky, N. 237

Katafuchi, Y. 296

Kendall, B. 400, 472

Kessler, C. 7, 394

Khoshbeen, A. 364

Kim, J.S. 269

Kluck, M. 372

Knoflach, P. 247

Kobayashi, K. 34

Kopp, S.J. 141

Kornhuber, H.H. 269

Kornhuber, J. 269

Kornhuber, M.E. 269

Kostić, V.S. 201, 291

Krause, K.-H. 394

Krivosic, I. 274

Kuda, N. 296

Kurachi, M. 34

La Mantia, L. 22

Larbig, W. 372

Larsen, J.L. 229

Leo, A. 51

Lesch, K.P. 73

Lesoin, F. 274

Liwnicz, B.H. 211

Loeb, C. 137

Luz, Y. 17

Mamoli, B. 247

Mancardi, G.L. 137

Mancini, A. 459

Marano, E. 51

Marbini, A. 173

Martin, J.J. 166

Martí-Vilalta, J.L. 12

Massa, S. 151

Mateo, D. 474 
Matsubara, R. 34

Meinck, H.M. 425

Meneghetti, G. 82

Merelli, E. 459

Messina, C. 221

Michielsen, P. 166

Mielke, U. 425

Mogami, H. 265

Morimoto, K. 265

Mörk, S. 229

Moroni, F. 104

Mozes, B. 237

Mrsulja, B.B. 201, 291

Najenson, T. 17

Nemni, R. 459

Neu, I.S. 132

Neuser, D. 73

Nguyen, J.P. 156

Nurchi, A.M. 56

Odajima, N. 144

Ono, E. 296

Ozaki, K. 265

Padberg, G. 26, 278, 435

Paganini, M. 104

Panić, M. 201

Parati, E.A. 22

Pelaghi, A.E. 56

Petit, H. 89

Pettegrew, J.W. 141
Piccardo, A. 151

Piccinin, G.L. 44

Piccirilli, M. 44

Pines, A. 237

Poirier, J. 156

Polc, P. 346

Probst, A. 466

Przuntek, H. 73

Rachele, M.G. 56

Reinecke, M. 425

Reuther, R. 7, 394

Roches, J.C. 466

Rondot, P. 252

Ross, E. 240

Rossier, A.B. 119

Saad, S. 182

Saia, A. 82

Sandyk, R. 92, 148, 163, 198, 479

Sartori, G. 95

Satoyoshi, E. 100

Sayar, Y. 237

Sazbon, L. 17

Scardigli, K. 240

Scherschlicht, R. 346

Schimrigk, K. 425

Schneider-Helmert, D. 353,358

Schoenenberger, G.A. 317, 321, 372

Schuller, E. 65

Scollo-Lavizzari, G. 1,466
Serena, M. 95

Skeidsvoll, H. 229

Snoeck, J. 166

Stam, F.C. 113

Stasch, J.P. 73

Steardo, L. 51

Sunohara, N. 100

Tabaton, M. 137

Tekian, A. 182

Testa, D. 22

Tissot, R. 364

Tsukagoshi, H. 144

Vacca, G. 459

Valade, D. 252

Vanagt, E. 166

Vanneste, J.A.L. 113

Van Sweden, B. 300

Vecchierini-Blineau, M.F. 449

Volpi, G. 459

Vrints, C. 166

Warot, P. 89

Watabiki, S. 144

Wikkelsö, C. 306

Yamaguchi, N. 34

Zaccara, G. 104

Zappoli, R. 104

Zeitlhofer, J. 247 
Acute inflammatory polyradiculoneuropathy 137

Adult type 425

Agar gel electrophoresis 306

Aging 141

Alcohol 364

Alexia 95

$\gamma$-Aminobutyric acid 269

Angiitis 459

Anoxia 141

Anterior spinal artery syndrome 119

Anticholinergics 474

Anti-elastin antibodies 394

Antitubercular therapy 148

Aphasia 95

Arterial occlusion 421

Arteriovenous malformation 206

Arteritis temporalis 407

AS hemoglobinopathy 22

Autoradiography 317

Axonal neuropathy 459

Azathioprine 394

Baclofen 51, 163

Basal ganglia 92

Basilar arteries 148

Benzodiazepine 1

Beta-endorphin 73

Binding 317

Blepharospasm 474

Blink reflex 221, 449

Blood-CSF barrier 132

Bobbing 151

Brain 141

Brain disease 229

Brain stem 148, 317

Brain tumor 229

Carbonate 92

Carbon monoxide poisoning 34

Cardiomyopathy 166

Carotid cross-clamping 82

Carotid endarterectomy 82

Catecholestrogen 26

CAT scan 7

Centronuclear myopathy 425

Cerebral angiography 400

Cerebral infarction 124, 201
Cerebral ischemia 82

Cerebral radionuclide angiography 124

Cerebral vasculitis 421

Cerebrospinal fluid 73

Cerebrospinal fluid proteins 306

Cervical spine sprain 119

Child 449

Childhood form 296

Childhood stroke 421

Chorea 26, 89, 278, 435

Chronic pain 372

Cimetidine 300

Circadian rhythm 321

Clinical study 12

Clofibrate 182

Clofibrate muscular atrophy 182

Clofibrate myopathy 182

Clofibrate neuropathy 182

Clonazepan 474

CNS infection 132

Colloid cyst 156

Coma 17, 151

Comparison 306

Complicated migraine 22

Computed tomography 34,124

Computerized cranial tomography 56

Computerized tomography 265

Congenital myopathy 425

Convulsions 296

Corticosteroids 407

Cranial computerized tomography 240

Crossed aphasia 95

CSF proteins 65

CT 466

CT scan 113

Cyclic AMP 201

Cystic astrocytoma 265

Cytomegalovirus mononucleosis syndrome 237

Cytostatic drugs 407

Deep dyslexia 95

Degenerative disorders of CNS 65

Delayed encephalopathy 34

Delta-sleep-inducing peptide 321

Dementia 44

Depression 372

Descending pain modulation 372 
Diagnosis 410

Diagnostic value 17

Distal myopathy 144

Dopamine 26

Dopamine-lithium carbonate interaction 92

Dopamine receptor supersensitivity 92

Drug dependence 386

DSIP 346, 353, 358, 364, 372, 386

Dysfunction 300

EEG 466

EEG-hypersynchrony 372

Electroencephalographic monitoring 82

Electromyography 425, 459

Electron microscopy 425

Electrophysiological studies 247

Epilepsy EEG 1

Epineurium 459

Eye movements 151,252

Fabry's disease 173

Facial nerve 163

Fahr's disease 265

Fibromuscular dysplasia 400

Flumazepil 1

Fluoroalkane 479

Giant cell arteritis 410

Glutamate 269

Guillain-Barré syndrome 137, 237

Haloperidol 92

${ }^{3} \mathrm{H}$-DSIP 317

Hemangiopericytic meningioma 274

Hemifacial spasm 163

Hemiplegia 17

Hemispheric lesions pattern 221

Hemorrhagic metatasis 240

HSV encephalitis 466

Human cerebrospinal fluid 201, 291

Huntington 89

Huntington's chorea 269

Huntington's disease 252, 296

Hyperammonemia 104

Hyperviscosity syndrome 26

Hypnagogic state 372

Hypokalemic periodic paralysis 100

IgE 394

IgG 132
Immune complex vasculitis 389

Immunofluorescence 7

Immunoglobulins 132

Immunohistochemical findings 394

Immunoperoxidase 211

Immunosuppressive therapy 7

Immunotherapy 132

Immunovasculitis 394

Inclusion bodies 211

Insomnia 358, 386

Internuclear ophthalmoplegia 148

Intraluminal shunt 82

Ischaemia 148

Ischaemic stroke 400

Isoelectric focusing 306

Juvenile ceroid lipofuscinosis 166

Lacunae 124

Leucine enkephalin 73

Levodopa treatment 44

Lipid inclusions 173

Lithium 92

Locked-in syndrome 137

Measles 211

Medial longitudinal fasciculus 148

Meige's syndrome 474

Mental retardation 296

Metabolic diseases 56

Methionine enkephalin 73

Minicores 425

Model insomnia 346

Mood 372

Morphine withdrawal 346

Motor dysfunction 479

Moya-Moya disease 400

Multifocal leukoencephalopathy 113

Multiple anticonvulsant therapy 104

Multiple sclerosis 65, 132

Myotonic dystrophy 144

Narcolepsy 353

Neurofibromatosis 400

Neuroleptics 269

Neuropathology 34

Neurotoxicity 300

Nitromethane 479

NMR 141

Nonapeptide 321 
Normal 17

Nosology 410

Nystagmus 151

Ocular movements 151

Oculogyric crises 92

Opiates 364

Oromandibular dystonia 474

${ }^{31} \mathrm{P} 141$

Pain 173

Pain control 372

Palmomental reflex 12

Papovavirus 113

Parameters 221

Parkinson's disease 44

Pathology 12

Peptides 358

Performance 353, 386

Perineurium and endoneurium 459

Periodic complexes 466

Peripheral neuropathy 459

Phosphate 141

Physiology 12

Pineal region 274

Piracetam 89

Polyarteritis nodosa 389,407

Polycythaemia 26

Polyneuropathy 247

Pontine hematoma 240

Pontine lesion 151

Postarachnoid radiculitis 51

Postherpetic neuralgia 51

Posture 252

Predictive tests 252

Primary biliary cirrhosis 247

Primitive reflexes 17

Prostaglandin $F_{2 a} 291$

Pyramidal signs 296

REM sleep 321

Rhythms 353

Risk factors 124

Ro 15-1788 1

Sarcoid granuloma 459

Schistosomiasis 229

Schizophrenia 269
Seizures 1

Sensory and motor recovery 119

Short PR syndrome 166

Sick sinus syndrome 166

Side effects 104

Silver staining 306

Sleep 353, 449

Sleep disturbances 321

Sleep-inducing factors 346

Sleep peptide 372

Sleep studies in animals 346

Sleep substance 358

Small vessel vasculitis 407

Stress resistance 321

Striatum 269

Stroke 206, 291, 421

Stump pressure 82

Subacute sclerosing panencephalitis 211

Subcortical hematoma 466

Sural nerve 173

Systemic lupus erythematosus $278,407,435$

$\mathrm{T}_{3}$ toxicosis 100

Tabes dorsalis 51

Tamm-Horsfall protein 65

Therapy 410

Thromboangiitis obliterans 7

Thyrotoxic periodic paralysis 100

Tissue culture 317

Trigeminal neuralgia 51

Tuberculous meningitis 148

Tumors of the third ventricle 156

Vascular malformation 240

Vasculitis 389,400

Vasculitis in connective tissue diseases 389

Vasculitis nervous system 407

Vasculopathy 459

Ventricular tachycardia 166

Ventromedian thalamus 321

VPA 104

Wegener's granulomatosis 389

Wilson's disease 56

Withdrawal treatment 364

Xanthogranuloma 156 